\title{
Kedudukan Anak Perempuan dalam Pembagian Harta Warisan menurut Hukum Islam (Studi Kasus Putusan Pengadilan Agama Medan No. 40/Pdt.G/2017/PA.Mdn)
}

\section{Position of Girls in Distribution of Inheritance according to Islamic Law(Case Study of Medan Religious Court Decision No. 40 / Pdt.G / 2017 / PA.Mdn)}

\author{
Emy Eliamega Saragih*, Mustamam \& Mukidi \\ Program Studi Magister Hukum, Fakultas \\ Hukum Universitas Islam Sumatera Utara, Indonesia
}

Diterima: Desember 2019; Disetujui: Desember 2019; Dipublish: Desember 2019

*Coresponding Email: emveliamegasaragih@gmail.com

\section{Abstrak}

Tujuan penelitian ini, mengenai posisi anak perempuan dalam distribusi hukum waris Islam, hak waris saudara kandung ayah yang meninggalkan anak perempuan dalam perspektif hukum Islam dan atas dasar pertimbangan hakim dalam menentukan penentuan ahli waris dalam keputusan kasir No. 40 / Pdt.G / 2017 / PA.Mdn. Penelitian dilakukan melalui pendekatan yuridis normatif dengan pendekatan kasus dengan menganalisis Putusan No. 40 / Pdt.G / 2017 / PA. Mdn) dan sumber data sekunder yang diperoleh dari hasil penelitian kepustakaan. Analisis data yang digunakan dalam penelitian ini adalah analisis data kualitatif. Berdasarkan hasil penelitian, bahwa posisi anak perempuan dalam distribusi hukum waris menurut Islam sama dengan posisi anak laki-laki, yaitu keduanya memiliki hak untuk mewarisi warisan orang tua atau saudara mereka. Hanya saja, porsi laki-laki lebih besar daripada bagian perempuan, yang merupakan dua bagian dari dua perempuan. Hak-hak warisan saudara kandung ayah yang meninggalkan anak perempuan dalam perspektif hukum Islam didasarkan pada bi ghairihi asabah, karena mereka mewarisi dari lelaki dan perempuan secara bersama-sama. Dasar pertimbangan hakim dalam menentukan penentuan ahli waris dalam putusan kasasi No. 40 / Pdt.G / 2017 / PA.Mdn, adalah Pasal 174 ayat (2) KHI dan Surat Pemeriksaan Al-Quran ayat 176 Panel hakim telah secara keliru menafsirkan substansi ujian paragraf 176 dan juga menafsirkan ketentuan Pasal 174 ayat (2) KHI.

Kata kunci: Posisi, Perempuan, Hukum Islam.

\section{Abstract}

The problem in this study, regarding the position of girls in the distribution of inheritance law according to Islam, concerning inheritance rights of siblings of fathers who leave a daughter in the perspective of Islamic law and on the basis of judges' consideration in determining the determination of heirs in the decision of case register No. 40/Pdt.G/2017/PA.Mdn. This research is a normative juridical approach with a case approach by analyzing Decision No. 40/Pdt.G/2017/PA. Mdn). The data source of this research is secondary data obtained from the results of library research. Data analysis used in this study is qualitative data analysis. Based on the research results obtained, that the position of girls in the distribution of inheritance law according to Islam is the same as that of boys, namely both have the right to inherit the inheritance of their parents or relatives. It's just that, the male portion is bigger than the female part, which is two parts of the two girls. The inheritance rights of the father's siblings who leave a daughter in the perspective of Islamic law are based on bi ghairihi asabah, because they inherit from men and women together. The basis of the judge's consideration in determining the determination of the heir in the decision of case register No. 40 / Pdt.G/2017/PA.Mdn, is Article 174 paragraph (2) KHI and Al-Quran Letter of Examination verse 176. The panel of judges has mistakenly interpreted the substance of the Examination paragraph 176 and also interpreted the provisions of Article 174 paragraph (2) KHI.

Keywords: Position, Women, Islamic Law.

How to Cite: Saragih, E.E., Mustamam \& Mukidi (2019). Kedudukan Anak Perempuan dalam Pembagian Harta Warisan menurut Hukum Islam (Studi Kasus Putusan Pengadilan Agama Medan No. 40/Pdt.G/2017/PA.Mdn). Journal of Education, Humaniora and Social Sciences (JEHSS). 2 (2): 307-317.

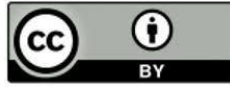




\section{PENDAHULUAN}

Masalah kewarisan dalam Islam menempati kedudukan yang amat penting, karenanya masalah kewarisan dijelaskan secara tegas dan terperinci di dalam Al-Quran. Hal ini dapat dimengerti, sebab masalah kewarisan pasti dialami oleh setiap orang. Sengketa antara ahli waris yang diputuskan secara litigasi melalui jalur pengadilan pada dasarnya bukanlah penyelesaian hukum yang terbaik, karena penyelesaian sengketa hukum yang terbaik adalah ketika para pihak mampu dan dapat duduk bersama mencari kata sepakat yang menghasilkan suatu kesepakatan bersama sebagai langkah penyelesaian.

Ketentuan hukum waris dalam Islam merupakan ketetapan yang datangnya dari Allah Subhanna Wata'ala. Oleh karena itu, maka dalam membagi harta warisan tetaplah mengacu pada ketetapan-ketetapan Allah dalam Al-Quran dan Hadist-hadist yang disampaikan oleh Rasulullah SAW., sebagai sumber utama dari hukum Islam (Simatupang \& Siregar, 2017; Rambe, 2017). Bagi umat Islam sudah menjadi suatu kewajiban untuk mentaati apa yang telah ditetapkan dan diperintahkan Allah Subhanna wata'la dan RasulNya sebagai bentuk perwujudan sikap Taqwa terhadap Allah Subhanna wata'la (Rofiq, 2013).

Sistem kewarisan Islam, kedudukan perempuan dengan laki-laki sama-sama sebagai ahli waris. Janda, anak perempuan, ibu dan saudara perempuan diakui kedudukannya sebagai ahli waris. Perbedaannya terletak pada porsi atau besarnya bagian harta warisan yang diterima (Zamzani, 2013)

Sengketa warisan biasanya berkenaan dengan masalah mengenai kelompok ahli waris yang berhak untuk mewarisi dan mengenai besarnya bagian dari masing-masing ahli waris (legitimatie portie). Salah satu contoh kasus sengketa kewarisan dapat dilihat pada kasus permohonan penetapan waris dalam register perkara No. 40/Pdt.G/2017/PA.Mdn. Perkara tersebut berkenaan dengan permohonan penetapan ahli waris. Perkara permohonan penetapan ahli waris dalam putusan register perkara No. 40/Pdt.G/2017/PA.Mdn, terdapat dua kelompok ahli waris, yaitu saudara sekandung dari pewaris (orang yang meninggal) dan isteri serta seorang anak perempuan dari pewaris (orang yang meninggal).

Permohonan penetapan ahli waris dalam putusan register perkara No. 40/Pdt.G/2017/PA.Mdn, kelompok ahli waris dalam hal ini terdiri dari : Isteri, seorang 
anak perempuan dan saudara sekandung dari ayah, bagaimana ketentuan hukum waris Islam mengatur bagian dari masing-masing ahli waris tersebut. Dalam penetapan Pengadilan Agama Medan pada register perkara No. 40 /Pdt.G/2017/PA. Mdn, yang menetapkan bahwa saudara sekandung dari Ayah atau Suami tidak berhak untuk mewarisi.

\section{METODE PENELITIAN}

Penelitian dilakukan melalui pendekatan yuridis normatif dengan pendekatan kasus dengan menganalisis Putusan No. 40 / Pdt.G / 2017 / PA. Mdn) dan sumber data sekunder yang diperoleh dari hasil penelitian kepustakaan. Analisis data yang digunakan dalam penelitian ini adalah analisis data kualitatif. Dalam penelitian ini menggunakan teori penerapan hukum Islam, teori maqashid al-syariah dan teori tujuan hukum. Mengenai penerapan hukum Islam, maka terdapat beberapa teori yang menjelaskan keberlakuan hukum Islam di Indonesia dan menjadi bagian sistem hukum di Indonesia, yaitu: a. Teori penerimaan otoritas hokum, Teori ini menggambarkan bahwa di dalam masyarakat Islam ada hukum Islam yang harus ditaati oleh orang-orang Islam karena telah diperintahkan oleh Allah. Oleh karena itu, mereka yang menerima Islam sebagai agamanya, maka mereka akan menerima otoritas hukum Islam terhadap dirinya (Zamzani, 2013)

Teori receptio in complexu digagas oleh Salomon Keyzer). Maksud teori ini, hukum mengikut agama yang dianut oleh seseorang, jika orang itu memeluk agama Islam, maka hukum Islamlah yang berlaku baginya (H. Amiur Nuruddin dan Azhari Akmal Tarigan, 2015). Terdapat dua alasan mendasar munculnya teori receptio in complexu, alasan pertama didasari pada hasil penelitian Hurgronje di Aceh, yang menunjukkan bahwa hukum yang berlaku dan berpengaruh bagi orang Aceh yang nota bene umat Islam bukanlah hukum Islam, dan hukum Islam baru kemudian memiliki kekuatan hukum kalau telah benar-benar diterima oleh Hukum Adat (Ali, 1991). Kedua, sebagaimana dikemukakan oleh Ichiyianto, bahwa teori ini muncul karena Hurgronje khawatir terhadap pengaruh pan Islamisme yang dipelopori oleh Sayid Jamaluddin Al-Afghani di Indonesia. Baginya jika umat Islam mengamalkan ajaran agamanya terutama sistem hukumnya secara menyeluruh (kaffah), maka umat Islam akan menjadi kuat dan sulit dipengaruhi tepatnya dijajah oleh Belanda (Ichtijianto, 1991). 
Teori receptio a contrario, yang dikemukakan oleh Sayuti Thalib mengandung makna bahwa hukum adat baru berlaku kalau tidak bertentangan dengan hukum Islam. Melalui teori ini jiwa pembukaan dan UUD 1945 telah mengalahkan Pasal 134 ayat (2) Indishce Staatregeling itu (Ichtijianto, 1991). Menurut Ismail Sunny setelah Indonesia merdeka dan UUD 1945 berlaku sebagai dasar negara kendati tanpa memuat ketujuh dair Piagam Jakarta, maka teori receptio dinyatakan tidak berlaku lagi dan kehilangan dasar hukumnya. Selanjutnya, hukum Islam berlaku bagi bangsa Indonesia yang beragama Islam sesuai dengan Pasal 29 UUD 1945. Era ini disebut oleh Ismail Sunny sebagai Periode Penerimaan Hukum Islam sebagai sumber persuasive (Ismail Sunny, 1998).

Awalnya maqashid syari'ah hanya merupakan bagian kecil dalam kajian ushul fiqih. Substansinya membahas seputar tujuan dan hikmah dari hukum-hukum syari'ah yang mencakup tiga bidang: Pertama, ibadah (ritual). Kedua, muamalah (interaksi sosial), dan Ketiga, jinayah (kriminal). Maqashid syari'ah juga bisa diklasifikasikan sebagai bagian dari filsafat hukum Islam (Ghilman Nursidin, 2012).

Tujuan penetapan hukum atau yang sering dikenal dengan istilah Maqashid alsyari'ah merupakan salah satu konsep penting dalam kajian hukum Islam. Karena begitu pentingnya maqashid al-syari'ah tersebut, para ahli menjadikan maqashid al-syari'ah sebagai sesuatu yang harus dipahami oleh mujtahid yang melakukan ijtihad. Adapun inti dari teori ini adalah mewujudkan kebaikan dan menghindarkan keburukan atau menarik manfaat dan menolak madharat (Fathurrahman Djamil, 2002).

Berdasarkan teori maqashid syari'ah, maka dalam mengkaji dan menganalisis serta mengatur perubahan atau perkembangan yang terjadi di masyarakat menurut hukum Islam senantiasa haruslah merujuk kepada Al-Quran dan As-sunnah sebagai sumber hukum utama, selain juga merujuk kepada pendapat para ulama melalui itjitihad.

\section{HASIL DAN PEMBAHASAN}

\section{Kedudukan Perempuan dalam Pembagian Harta Warisan}

Kedudukan anak atau kaum perempuan dalam pembagian harta warisan di Indonesia dapat dilihat dari beberapa sistem hukum kewarisan yang berlaku di Indonesia, yaitu sistem hukum adat, KUHPerdata, dan sistem hukum kewarisan Islam yang terkandung di dalam $\mathrm{KHI}$. 
Sistem hukum kewarisan adat mengenal tiga sistem kewarisan, individual, kolektif, dan mayorat. Sistem kewarisan individual para ahli waris mewarisi secara perorangan. Harta peninggalan dibagikan kepemilikannya kepada para ahli waris. Kebaikan dari sistem ini adalah kepemilikan harta secara pribadi. Para ahli waris dapat bebas menguasai dan mempergunakan sesuai kebutuhan masing-masing tanpa dipengaruhi anggota keluarga yang lain. Kelemahan dari sistem ini adalah potensi terjadi perpecahan harta warisan dan merenggangnya tali kekerabatan. Sistem ini berlaku di lingkungan masyarakat adat Batak, Jawa, Sulawesi, dan lain-lain (Soekanto, 2008)

Sistem kewarisan Kolektif adalah para ahli waris mewarisi harta peninggalan secara kolektif. Harta peninggalan tidak dibagi secara perseorangan. Kebaikan dari sistem ini adalah bila fungsi harta kekayaan diperuntukkan bagi kelangsungan harta anggota keluarga tersebut. Kelemahan yang terdapat pada sistem ini yaitu menimbulkan cara berfikir yang sempit, kurang terbuka karena selalu terpancang pada kepentingan keluarga saja (Soekanto, 2008)

Adapun sistem kewarisan mayorat adalah harta peninggalan diwarisi keseluruhannya atau sebagian besar (sejumlah besar harta pokok dari suatu keluarga) oleh seorang anak saja. Sistem ini ada dua macam, mayorat laki-laki seperti yang berlaku di masyarakat adat Lampung dan mayorat perempuan (Tunggu Tubang), seperti yang berlaku di masyarakat adat Semendo, Sumatera Selatan (Soekanto, 2008)

Sistem kewarisan Adat sangat dipengaruhi oleh sistem kekerabatan (kekeluargaan). Berdasarkan genealogis yang terdapat dalam masyarakat Adat di Indonesia, terdapat beberapa tipoligi sistem kekerabatan, yaitu patrilineal, matrilineal dan parental.

Sistem kewarisan menurut KUHPerdata, menurut Hukum Perdata Barat tata cara pembagian harta warisan dibagi menjadi dua prosedur, yaitu pewarisan berdasarkan undang-undang (ab intestato) dan pewarisan berdasarkan wasiat (testament) (Suparman Usman, 1990). Pewarisan menurut undang-undang adalah pembagian harta warisan kepada orang-orang yang mempunyai hubungan darah yang terdekat dengan pewaris sebagaimana ditetapkan undang-undang (Suparman, 2015)

Pewarisan berdasarkan undang-undang biasanya disebut dengan istilah "warisan karena kematian" atau ab intestate (Perangin, 2014) Pewarisan berdasarkan undangundang ini terdiri dari dua kategori, pertama, pewarisan berdasarkan kedudukan sendiri, 
yaitu ahli waris yang mewarisi harta warisan secara langsung dari pewaris, kepala demi kepala (sama rata). kedua, pewarisan berdasarkann penggantian, yaitu ahli waris yang mewarisi harta warisan karena menggantikan kedudukan ahli waris yang sebenarnya berhak mewarisi lantaran ahli waris tersebut telah meninggal lebih dahulu (Suparman, 2015)

Kedudukan perempuan menurut sistem kewarisan KUHPerdata dapat dilihat dalam Pasal 852 a KUHPerdata menegaskan bahwa suami atau isteri (janda atau duda) mendapatkan bagian yang sama dengan anak. Ketentuan yang mempersamakan janda atau duda mendapatkan bagian yang sama dengan anak ini hanya berlaku dalam pewarisan menurut undang-undang. Jadi baik janda maupun duda tidak selalu sama dengan anak, karena janda atau duda tidak berhak atas legitieme portie (bagian mutlak).

Prinsipnya dalam kewarisan KUHPerdata, ahli waris yang termasuk dalam Golongan I terdiri dari anak dan suami/isteri mendapat bagian yang sama besar. Sesuai dengan ketentuan Pasal 852 KUHPerdata, yang menyebutkan: "Bilamana anak dari orang yang meninggal masih hidup, maka anak-anak itu beserta dengan janda memperoleh masing-masing suatu bagian yang sama".

\section{Sistem Kewarisan Islam}

Kedudukan anak perempuan sebagai ahli waris telah ditentukan dalam Al-Quran surat An-Nisa (4: 11), yang artinya: "Allah mensyariatkan bagimu tentang (pembagian pusaka untuk) anak-anakmu, yaitu bahagian seorang anak laki-laki sama dengan bahagian dua orang anak perempuan".

Ayat di atas memberikan penjelasan bahwa Allah Subhana Wata'ala menetapkan bagian satu orang anak laki-laki sama dengan bagian dua orang anak perempuan. Dengan demikian, jika seseorang meninggalkan seorang anak laki-laki dan dua orang anak perempuan, maka dalam kasus ini anak laki-laki mendapat bagian dua pertiga dan saudara perempuannya mendapat bagian satu pertiga dari harta warisan (Muthiah \& Hardani, 2015).

Di negara Indonesia, kedudukan anak perempuan dalam kewarisan Islam dapat dilihat dalam rumusan Pasal $176 \mathrm{KHI}$, yang menyebutkan "anak perempuan menjadi ahli waris bersama-sama anak laki-laki, maka bagian anak laki-laki adalah dua berbanding 
satu dengan anak perempuan". Ketentuan pasal ini sangat bersesuaian dengan ketentuan yang dijelaskan Allah Subhana Wata'la di dalam Al-Quran surat Annisa (4: 11).

Sistem kewarisan Islam menempatkan anak perempuan pada kedudukan yang sama dengan anak laki-laki, yaitu sama-sama berhak menjadi ahli waris. Hanya saja terdapat perbedaan mengenai besarnya bagian yang diterima, yaitu bagian anak laki-laki lebih besar dari anak perempuan, yaitu dua bagian dari anak perempuan.

\section{Hak Mewarisi Dari Saudara Sekandung Dari Ayah Yang Meninggalkan Seorang Anak Perempuan Dalam Perpektif Hukum Islam}

Menurut sistem kewarisan Islam, saudara yang menjadi ahli waris adalah saudara sekandung, baik laki-laki maupun perempuan. Saudara seayah, baik laki-laki maupun perempuan. Saudara seibu, baik laki-laki maupun perempuan.

Sumber hukum yang menjadi dalil hak mewarisi saudara sebagai ahli waris adalah Al-Quran Surat An-Nisa 11, 12 dan ayat 176. Sebagian ahli tafsir mengatakan bahwa ketentuan yang terkandung dalam Al-quran Surat An-Nisa ayat 12 dikhususkan untuk saudara seibu, baik laki-laki maupun perempuan, sedangkan pada ayat 176 ditujukan untuk saudara sekandung atau saudara seayah, baik laki-laki maupun perempuan (Rahman, 1999).

Jumhur ulama sepakat bahwa yang dimaksud saudara-saudara dalam surat An-Nisa ayat 12 bukan selaku ashabah. Pengertian Ashabah yang sangat masyur dikalangan ulama faraid ialah orang yang menguasai harta waris karena ia menjadi ahli waris tunggal. Selain itu, Ashabah menerima sisa harta warisan setelah ashabul furudh menerima dan mengambil bagian masing-masing. Yang dimaksud saudara dalam ayat ini adalah saudara seibu, sebab jika mereka itu saudara sekandung atau seayah tentulah berkedudukan selaku ashabah sebagaimana dijelaskan pada akhir surat An-nisa ayat 176: (..."Dan jika mereka terdiri dari saudara laki-laki dan perempuan, maka untuk yang laki-laki sebanyak bagian dua orang saudara perempuan").

Pendapat Jumhur ini kemudian diikuti oleh KHI sebagaimana diatur dalam Pasal 181 dan 182 KHI. Pasal 181 KHI menyebutkan: "Bila seorang meninggal tanpa meninggalkan anak dan ayah, maka saudara laki-laki dan saudara perempuan seibu masing-masing mendapat seperenam. Bila mereka itu dua orang atau lebih, maka 
mereka bersama-sama mendapat sepertiga". Selanjutnya pada Pasal 182 KHI, menyebutkan :

Bila seorang meninggal tanpa meninggalkan ayah dan anak, sedang ia mempunyai satu saudara perempuan kandung atau seayah, maka ia mendapat separoh bagian. Bila saudara perempuan kandung atau seayah tersebut bersama-sama dengan saudara perempuan kandung atau seayah dua orang atau lebih, maka mereka bersama-sama mendapat dua pertiga bagian. Bila saudara perempuan tersebut bersama-sama dengan saudara laki-laki kandung atau seayah, maka bagian saudara laki-laki adalah dua berbanding satu dengan saudara perempuan.

Berdasarkan uraian di atas, dapat diketahui kedudukan saudara sekandung dalam kewarisan Islam termasuk dalam kelompok ashabul furudh, yaitu ahli waris yang telah ditetapkan bagiannya dalam Al-quran, As-Sunnah dan ij'ma para ulama. Demikian pula dalam KHI, mengenai besarnya bagian dari masing-masing saudara sekandung baik perempuan maupun laki-laki telah disebutkan secara jelas dan terperinci.

\section{Dasar Pertimbangan Hakim Dalam Menentukan Penetapan Ahli Waris Dalam Putusan Register Perkara No. 40/PDT.G/2017/PA. Mdn}

Majelis hakim dalam pertimbangannya telah mendalilkan Pasal 174 ayat (2) sebagai dasar hukum dalam menetapkan ahli waris yang mustahak atas harta peninggalan alm. H. Muchtar Rangkuti, dengan ketentuan bahwa jika semua ahli waris ada, maka yang berhak mendapat bagian warisan adalah suami atau isteri, anak, ayah dan ibu. Dalam hal ini hakim berkesimpulan bahwa karena isteri dan anak perempuan masih ada, maka hak ahli waris lainnya yang masih memiliki hubungan darah dengan si pewaris akan tertutup (terhijab) haknya untuk mendapatkan ahli waris. Selanjutnya, majelis hakim dalam pertimbanganya juga mendalilkan ketentuan yang terkandung dalam Al-quran surat An-nisa ayat 176, yang artinya :

Mereka meminta fatwa kepadamu tentang kalalah. Katakanlah: "Allah memberi fatwa kepadamu tentang kalalah (yaitu): jika seorang meninggal dunia, dan ia tidak mempunyai anak dan mempunyai saudara perempuan, maka bagi saudaranya yang perempuan itu seperdua dari harta yang ditinggalkannya, dan saudaranya yang laki-laki mempusakai (seluruh harta saudara perempuan), jika ia tidak mempunyai anak; tetapi jika saudara perempuan itu dua orang, maka bagi keduanya dua pertiga dari harta yang 
ditinggalkan oleh yang meninggal. Dan jika mereka (ahli waris itu terdiri dari) saudarasaudara laki dan perempuan, maka bahagian seorang saudara laki-laki sebanyak bahagian dua orang saudara perempuan. Allah menerangkan (hukum ini) kepadamu, supaya kamu tidak sesat. Dan Allah Maha Mengetahui segala sesuatu.

Menurut penulis, pertimbangan hakim dalam menetapkan ahli waris yang mustahaq dalam hal ini telah terjadi kekeliruan dalam menafsirkan ketentuan Pasal 174 ayat (2) KHI dan juga menafsirkan Ayat Al-quran yang terdapat dalam Surat An-Nisa ayat 176. Kekeliruan tersebut jelas tampak bahwa maksud dari Pasal 174 ayat (2), adalah bahwa jika dalam suatu keadaan semua ahli waris ada, artinya terdapat ahli waris utama, yaitu suami atau isteri, anak laki-laki maupun anak perempuan, ayah dan ibu, dimana kesemua ahli waris ini tidak bisa tertutup (terhijab).

Apabila terdapat keadaan dalam suatu pewarisan, seorang suami meningggalkan seorang isteri dan seorang anak perempuan, sementara ayah dan ibu sudah terlebih dahulu meninggal, maka kedudukan saudara sekandung akan menjadi ashabah, karena ayah dan ibu tidak ada. Jika saudara kandung hanya seorang laki-laki atau lebih, maka akan menjadi ashabah bi nafsi. Kemudian apabila, terdapat saudara sekandung laki-laki bercampur dengan perempuan, maka kedudukan saudara sekandung ayah akan menjadi ashabah bi ghahiri, yang mendapat sisa pembagian harta peninggalan.

Dalil saudara sekandung berkedudukan sebagai ashabah bi ghahiri, yaitu Al-quran surat An-nisa ayat 176. Ketentuan ayat ini menerangkan ahli waris dalam keadaan kalalah, jika tidak memiliki keturunan dan tidak memiliki ayah, sehingga saudara sekandung dan saudara sebapak berhak mendapatkan bagian. Namun, dalam keadaan si pewaris meninggalkan seorang isteri dan seorang anak perempuan, maka kedudukan saudara sekandung ayah tidaklah termasuk dalam mahjuz (Rahman, 1999), sehingga hak ahli warisnya (tertutup) dan tidak dapat sama sekali memperoleh bagian dari harta peninggalan. Melainkan termasuk dalam hijab nugshan, yaitu bergesernya hak seorang ahli waris dari bagian yang besar menjadi bagian yang kecil karena adanya ahli waris lain yang memengaruhinya (Rahman, 1999). Tertutupnya ahli waris secara mutlak termasuk dalam hijab hirman, yaitu tertutupnya (hilangnya) hak seorang ahli waris untuk seluruhnya, karena ada ahli waris yang lebih utama daripadanya, seperti saudara kandung yang terhijab dengan adanya anak laki-laki atau cucu laki-laki dan bapak (Rahman, 1999). 


\section{SIMPULAN}

Kedudukan anak perempuan dalam pembagian hukum warisan menurut Islam adalah sama dengan anak laki-laki, yakni sama-sama berhak untuk mewarisi harta peninggalan orang tuanya atau kerabatnya. Hanya saja, bahagian laki-laki lebih besar dari bagian perempuan, yaitu dua bagian dari bagian dua orang anak perempuan. Hak mewarisi dari saudara sekandung dari ayah yang meninggalkan seorang anak perempuan dalam perpektif hukum Islam, berkedudukan sebagai ashabah bi ghairihi, karena secara bersama-sama mewarisi antara laki-laki dan perempuan. Sedangkan besarnya hak dari saudara adalah sisa dari pembagian ashabul furud, yaitu setelah isteri dan seorang anak perempuan mengambil bagiannya masing-masing.

Dasar pertimbangan hakim dalam menentukan penetapan ahli waris dalam putusan perkara No. 40/Pdt.G/2017/PA.Mdn adalah Pasal 174 ayat (2) KHI dan AlQuran Surat An-nisa ayat 176. Namun, majelis hakim telah keliru menafsirkan substansi ayat 176 dan menafsirkan Pasal 174 ayat (2) KHI. Kesalahan penafsiran tersebut menyebabkan terjadinya kekeliruan dalam menetapkan ahli waris yang mustahak dalam permohonan penetapan ahli waris yang diajukan para pemohon, sehingga saudara sekandung dari alm. H. Muchtar Rangkuti tidak mendapatkan harta peninggalannya, karena terdinding (terhijab).

\section{DAFTAR PUSTAKA}

Ali, D.M. (1991). Hukum Islam; Peradilan Agama dan Masalahnya, Bandung; Rosakarya. Assahabuni, A.M. (1995). Pembagian Waris Dalam Islam, Jakarta; Gema Insani Press. Djamil, F. (2002). Filsafat Hukum Islam, Jakarta; Logos Wacana Ilmu.

Hardani, P.S.N. \& Aulia, M. (2015). Hukum Waris Islam, Yokyakarta; Pustaka Yustisua. Ichtijianto, (1991). Pengembangan Teori Hukum Islam di Indonesia, Bandung; Rosakarya. Perangin, E, (2014). Hukum Waris, Cet- ke 14, Jakarta; Rajawali Pers.

Rahman, F. (1999), Ilmu Waris, Jakarta; Bulan Bintang.

Rofiq, A, (2013). Hukum Perdata Islam di Indonesia. Jakarta; RajaGrafindo Persada.

Soekanto, S, (1991). Hukum Adat Indonesia, Jakarta; Raja Grafindo Persada.

Sunny, I. (1998). Tradisi dan Inovasi Keislaman di Indonesia dalam Bidang Hukum Islam, Jakarta; Logos Publishing.

Suparman, M. (2-015). Hukum Waris Perdata, Jakarta; Sinar Grafika.

Tarigan, A.A. \& Amiur. (2015). Perdata Islam Di Indonesia, Studi Kritis Perkembangan Hukum Islam dan Fikih, UU. No. 1 Tahun 1974 sampai KHI, Jakarta; Prenada Kencana Media Group.

Usman, S. (1990). Ikhtisar Hukum Waris Menurut Kitab Undang-undang Hukum Perdata (BW), Serang; Darul Ulum.

Zamzani, M, (2013). Perempuan dan Keadilan Dalam Hukum Kewarisan Indonesia, Jakarta; Prenada Kencana Media Group.

Nursidin, G. (2012). Kontruksi Pemikiran maqashid syari'ah Imam Al-Haramin Al-Juwaini (Kajian SosioHistoris), Tesis, Program Pasca Sarjana IAIN, Semarang

Simatupang, B.L.G. \& Siregar, T. (2017). Tinjauan Yuridis Akibat Perceraian Terhadap Harta Gono-Gini . Jurnal Ilmiah Penegakan Hukum, 4 (2) 2017: 30-35. 
Rambe, K.M., (2017), Hak-Hak Perempuan Dalam Hukum Islam (Studi Pemikiran Ashgar Ali Engineer), Mercatoria, 10 (2): 109-127. 